\title{
Is Islam Against Science \& Technology?
}

\author{
Saifullah Bhutto ${ }^{1, *}$, Abdul Rehman Kaloi ${ }^{2}$ and Hameedullah Bhutto ${ }^{3}$ \\ 'Quaid-e-Awam University, Nawabshah, Pakistan \\ 2University of Sindh, Jamshoro, Pakistan \\ 3 University of Sindh, Mirpurkhas Campus, Pakistan
}

\begin{abstract}
Article Type: Article
Article Citation: Saifullah Bhutto, Abdul Rehman Kaloi, Hameedullah Bhutto. Is Islam against science \& technology? Indian Journal of Science and Technology. 2020; 13(10), 1148-1159. D0l: 10.17485/ijst/2020/ v013i10/149741
\end{abstract}

Received date: December 19, 2019

Accepted date: January 22, 2020

*Author for correspondence: Saifullah Bhutto bhuttosaifullah@ quest.edu.pk 9 Quaid-e-Awam University, Nawabshah, Pakistan

\begin{abstract}
Objectives: There is a common misunderstanding that religion and science are contradictory to one another and hence religion is hindrance in progress and development. This study emphasizes the importance of acquiring the knowledge of science \& technology from an Islamic perspective and tries to remove the misconception about prohibition of adopting the science $\&$ technology in religion. Researchers have tried their best to establish the fact that there is no contradiction between religion \& science. Methods: Interpretive method of research has been used in this study. The researchers have used historical facts for demonstrating the role played by ancient and current scholars in the development of science \& technology. Data from several past \& present research materials have been collected and theory of compatibility of religion with science \& technology has been established from the observed data. Findings: Islamic civilization is based on knowledge and awareness. The first revelation was about the reading. In Quran and Hadith, whenever and wherever the word knowledge is mentioned, it does not refer to religious knowledge only but in fact the word knowledge refers to any science which may benefit human beings from material and spiritual perspective. Application/improvements: There is a common perception that religion obstructs the involvement of people in science \& technology. Authors have proved in this study that the situation is contrary. This is only a small glimpse of wide picture of role played by Islam in encouraging active participation in the advancement of science \& technology.
\end{abstract}

Keywords: Quran, Science, Knowledge, Technology, Hadith.

\section{Introduction}

The Quran is full of verses focusing on the importance of knowledge, encouraging the act of thinking and meditation to bring the peace and harmony within self and society. The Quran taught prophet to pray for increase in knowledge (Al-Quran 20:114) and it announced that those who know and those who do not know are not equal (Al-Quran 
39:09). Those who know have privilege over those who do not know (Al-Quran 58:11). We are living in the age of science and technology and scientific tools and systems have become inevitable part of life. Technological developments in the world today have brought a lot of changes to human life. Besides helping with daily life and facilities, the advancement of technology has also an impact on the dissemination of information \& knowledge. This is because the use of technology greatly helps the public to access information far more easily and quickly than earlier times. In [1] this article, we have expressed Islamic perspective regarding the science \& technology by shedding light on the significance of knowledge in Quran \& Hadith and contribution of early \& contemporary Muslim scholars in the fields of science \& technology.

\section{Significance of Knowledge in Quran}

Islam gives utmost importance to knowledge, and it is evident from the fact that the first revelation to prophet Muhammad was about reading (Al-Quran 96:1-5). Not only this but the Quran contains verses in abundance which depict the significance of knowledge. For example, in verse no. 11 of chapter no. 58 Allah says: "Allah will exalt in degree those of you who believe and those who have been granted knowledge." Furthermore, he says in verse no. 9 of chapter no. 39 "Are those who know equal to those who know not?" [2]. Prophet Muhammad S.A.W was taught to pray for increase in knowledge (Quran 20:114). The word Knowledge (קلع) has appeared in its various forms of verb, adjective, noun, etc. for 777 times in Quran. While the word Qara (أرق) which means "reading with understanding" has appeared in different forms for 88 times in Quran. The word Fakar (ركف) meaning "giving thought/considering/reflecting upon/pondering" has appeared in different forms for 18 times in Quran. The word Aql (لققع) meaning "understanding/using sense" has appeared in different forms for 49 times in Quran. The word Tala (الت (الت meaning "recitation/reading" has appeared in different forms 63 times in Quran [3]. This reflects to immense importance given to knowledge and awareness in Islam.

It is pertinent to mention that wherever in Quran, knowledge is mentioned it does not refer to religious knowledge only but there is a great deal of Quranic verses which talk about the scientific facts. The scholars have worked a lot on it, and they have found that there are almost one thousand verses which deal with scientific facts [4]. These verses belong to various fields of science, for example, Astrology, Physics, Geology, Oceanology, Botany, Zoology, Medicine, Genetics, and Anatomy, etc.

We must admit that Quran is not the book of science, but it is a book of guidance primarily and it guides by showing signs of the presence of Allah in the universe. The diversity of scientific dimensions present in Quran shows that Islam never opposes involvement in scientific activities, rather it appreciates and encourages to be scientific in approach.

\section{Significance of Knowledge in Hadith}

Countless sayings of the prophet about encouragement of seeking knowledge have been reported to the extent that chapters in books have been specified to elucidate the topic or 
the whole books have been written on the issue. We quote some of the Prophet's sayings which promote the scientific activity below:

The Prophet Muhammad (P.B.U.H) said: "God, His angels and all those in Heavens and on Earth, even ants in their hills and fish in the water, pray for those who are busy in seeking knowledge, a scholar has privilege over a worshipper like moon has privilege over all stars, scholars are the heirs of prophets as the prophets never leave dinar and dirham but they leave knowledge in heritance" [5].

Prophet not only encouraged people of his time to seek knowledge, but he interceded in anticipation for the people of future who would engage themselves in scientific activities by saying: "When people come to you to seek knowledge, greet them on behalf of me and teach them" [6].

He also categorized the knowledge into beneficial \& harmful and instilled into his followers a determination and zeal for acquiring beneficial knowledge: "Seek from Allah useful knowledge and seek refuge in Him from the knowledge which does not benefit".

He announced that knowledge is beyond the boundaries of countries and cultures and travelling for the purpose of acquiring knowledge is a desirable act: "Whoever walks a path in which he seeks knowledge, Allah will ease his way to paradise". "Whoever goes out to seek knowledge is in the way of Allah until he returns" [7].

And above all, he considered seeking of knowledge as obligation by saying: "Seeking knowledge is compulsory on every Muslim, male or female". That means education is basic right of everyone and no one should be deprived of it irrespective of gender and race.

\section{Significance of Acquiring Scientific and Technological Knowledge in Islam}

As we have mentioned above that in Quran there are many verses that are purely scientific in nature and hence indicate the tendency and proneness of religion for science and technology. We will quote some of them as example:

The story of Prophet Solomon is mentioned in detail in different parts of Quran that he was given the miraculous power over the winds and could make them obey his orders. We may say the same of airmen of the present day [8].

Exploration of the universe has been clued in verse no. 33 of surah Rahman: "O assembly of jinns and men! If you have power to pass beyond the zones of the heavens and the earth, then pass (them)! But you will never be able to pass them, except with authority (from Allah)!"

Verses like this are probably the inspiration source for earlier Islamic scholarship that majority of ancient Muslim scientists were interested in Astronomy, Physics, \& Cosmology.

Similarly, Prophet Solomon was taught to make coats of mail as defensive armor. This points out to the vocational \& technical education. We find the traces of establishment of polytechnic institutes (Dar al-Funun) in the early 19th century in Iran by Europe-educated elites, and other courtiers educated in Tabriz dar al-saltana [9].

Allah commands the Muslims to travel throughout the world in order to see the fate of those who rejected the truth (al-Quran, 29:20). The field Archaeology (The least attended area by Muslims unfortunately) is clued in this verse. 
Another divine command imposes a permanent obligation upon Muslims to prepare the maximum possible force and war material so that they could be able to frighten their enemies (al-Quran 8:60). This teaches Muslims not only to be updated, but eye on future technologies so that they may not remain behind.

A phrase "Seek knowledge even if you have to go to china" is commonly quoted as the saying of prophet by scholars. Though some Hadith experts doubt the originality and authenticity of this Hadith on technical grounds but Dr. Hameedullah considers that Hadith as authentic \& sound on historical grounds. He writes: "An international annual expo used to be held every year at the place of Daba in Amman, businessmen from Iran, China, India and Sindh used to participate in that expo and display their products. Prophet, being the merchant used to visit that expo and he possibly met Chinese people there and was impressed by their skills in silk products and then he would have said that statement" [10].

\section{Contribution of Muslims Towards Science and Technology}

A tremendous cultural and intellectual transformation in the history of human civilization was brought about in early Muslim societies by the Qur'an. It supplied a new basis for the early Muslims' efforts in constructing a new civilization [11]. Muslim scientists were successful in their contributions to science and civilization when they maintained the nexus between existential reality and its metaphysical dimension, atheo-centric value order that guided their scientific enquiry, and their quest for knowledge and truth [12]. Influenced and inspired by Quran's scientific approach towards human problems, Muslims have contributed actively in all branches of science in every age. We will discuss their role briefly.

\subsection{Contribution of Early Muslim Scholars}

Islam is the religion of knowledge. Knowledge and Islam are synergic with one another and Islamic civilization without knowledge is simply unimaginable. The interconnectivity of Islam and knowledge and both being complementary to one another is evident from the fact that early Muslim scholars were not restricted to Islamic sciences only, but they had expertise in physical \& natural sciences as well. In fact, earlier Muslim Scholars did not have the concept of Islamic and non-Islamic sciences.

1- Abu Reyhan al-Biruni (973-1048 A.D): Biruni is regarded as one of the greatest scholars of the medieval Islamic era and was well versed in physics, mathematics, astronomy, and natural sciences, and also distinguished himself as a historian, chronologist, and linguist. See Figure 1 [13].

2- Muhammad b. Zakariyya al-Razi (865-925 A.D): Physician and Chemist. Authored 12 books on Chemistry. Author of Kitabul Asrar (Book of Secrets) on Chemistry and al-Haawi an encyclopaedic book on medicine. He explained different phases of moon through diagrams. See Figure 2 [14]. 


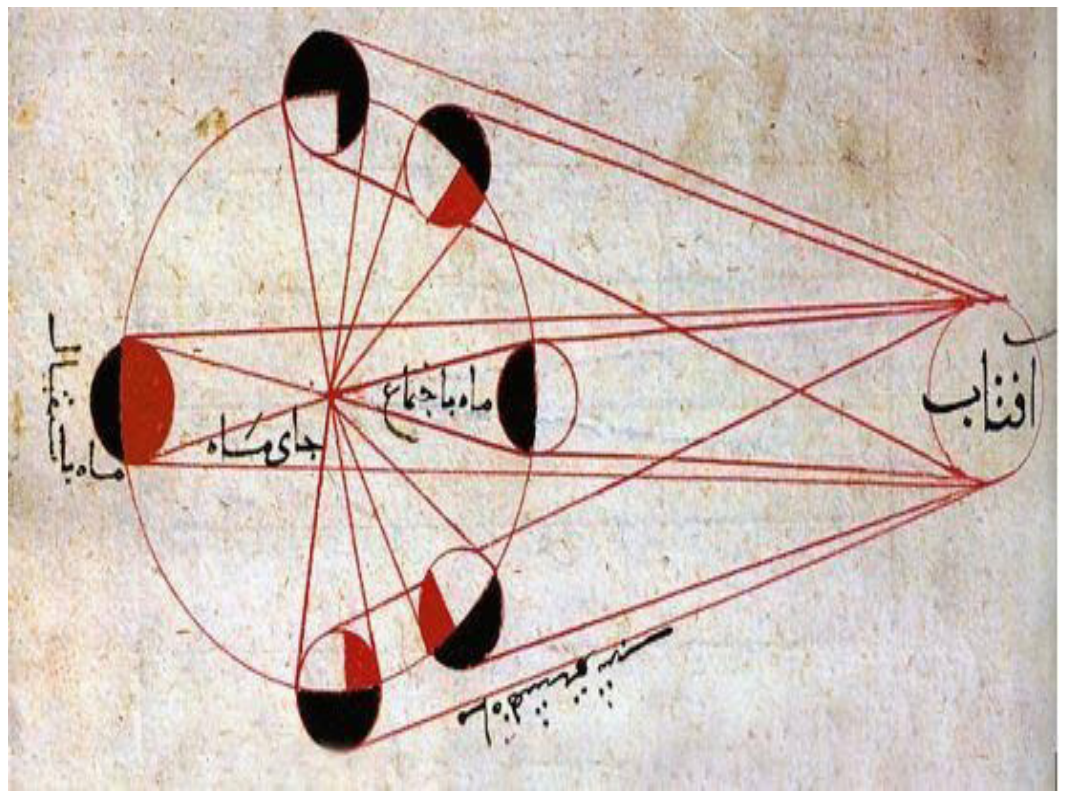

FIGURE 1. Illustration by Al-Biruni of different phases of the moon from kitab al-Tafhim. Source: http://www.alamy.com. Accessed on 10/07/2019.

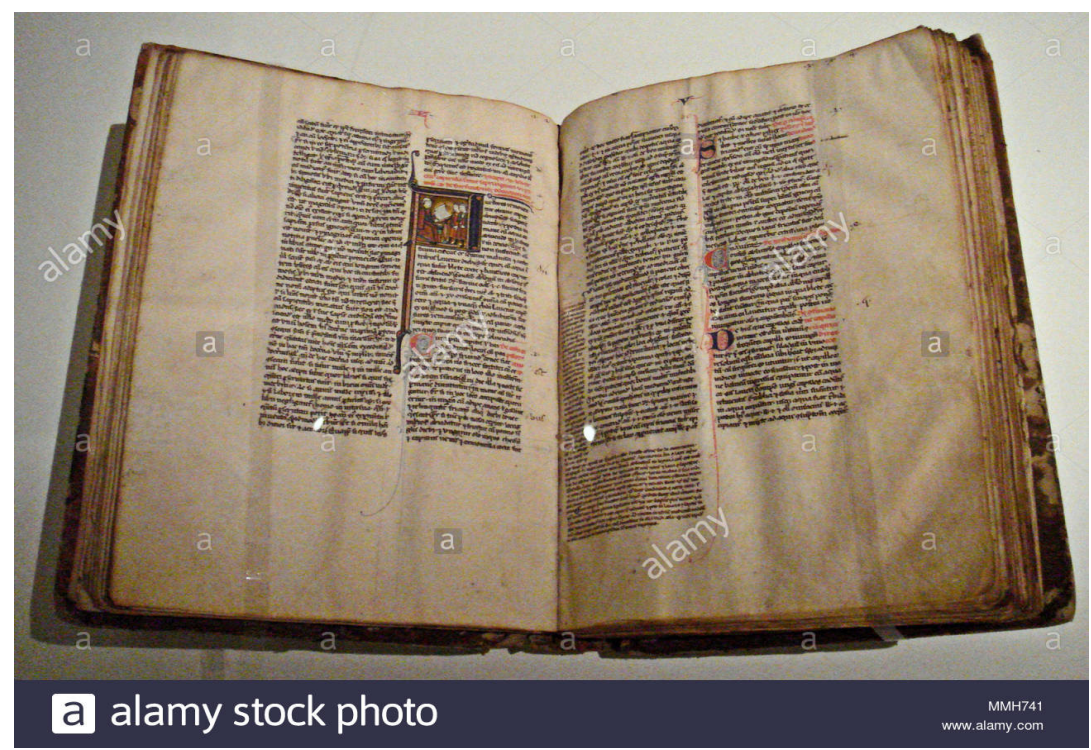

FIGURE 2. Al-Razi's book on medicine. Source: http://wwww.alamy.com/english-al-razi. Accessed on 10/07/2019.

3- Ibn Sina (980-1037 A.D): Commonly known as Avicenna in Western world. The great physician, philosopher, and author of famous book "al-Qanun fi al-Tibb". East Germany in 1952 and Hungry in 1987 issued postage stamp in the recognition of services to science and technology rendered by Avicenna. See Figures 3 and 4. 


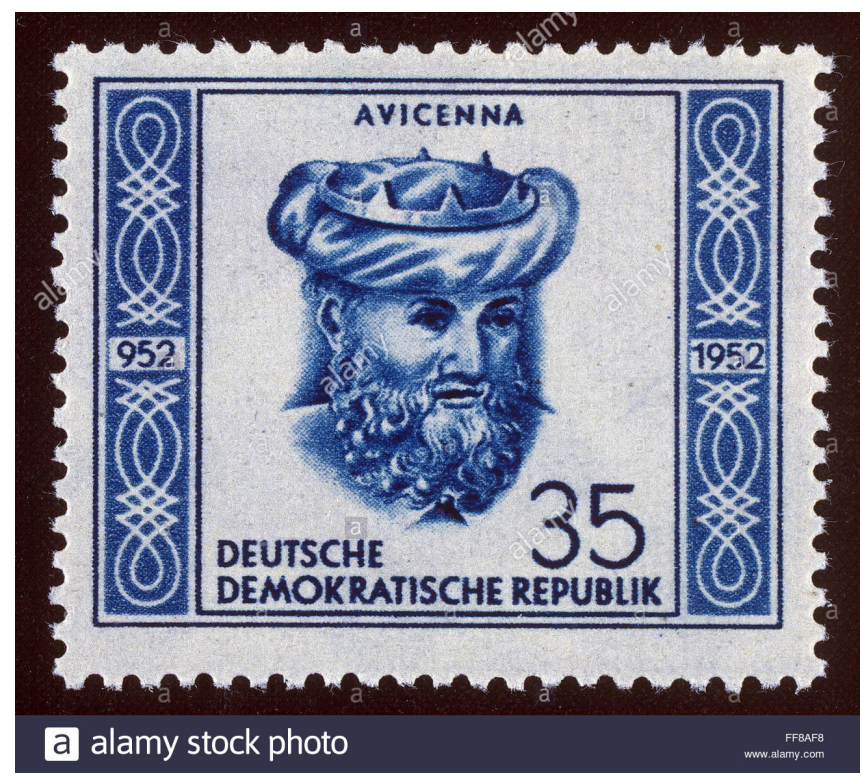

FIGURE 3. Postage stamp issued by East Germany in 1952 in the recognition of services to science \& technology rendered by Avicenna. Source: http://wwww.alamy.com/stockphoto-avivcenna-ibn-sina-n980-1037-muslim-philosopher-and physician. Accessed on 10/07/2019.

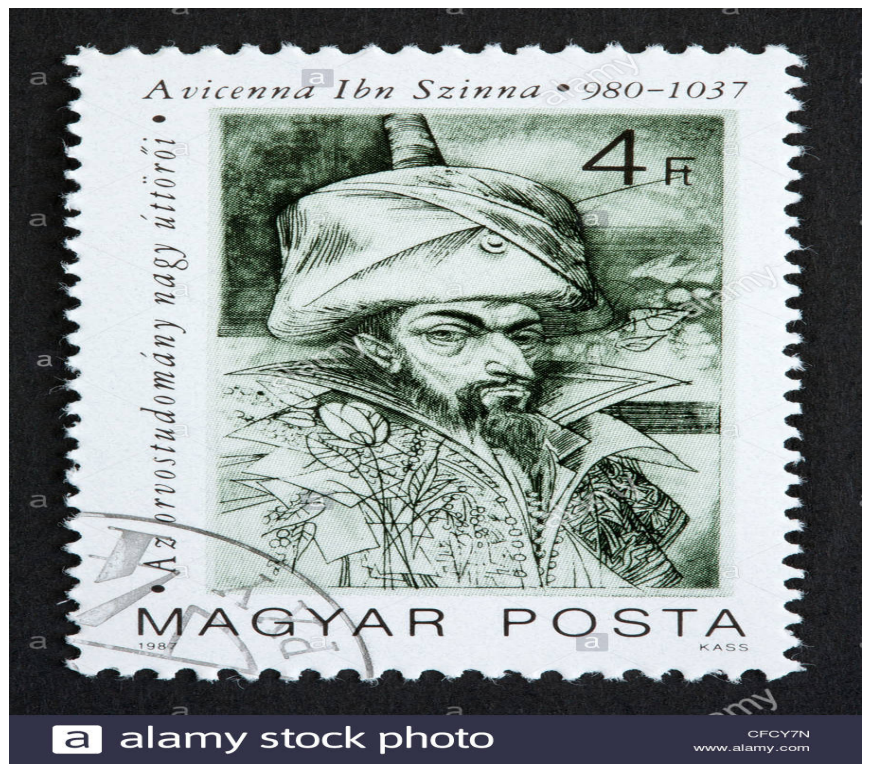

FIGURE 4. Postage stamp issued by Hungry in 1987 in the recognition of services to science and technology rendered by Avicenna. Source: https://www.alamy.com.

4- Muhammad ibn Musa al-Khwarizmi (780-850 A.D): The father of Algebra. An Iraqi Astronomer and Mathematician who developed a set of astronomical tables. The 
Russian government issued a postage stamp in 1983 in the recognition of services rendered by al-Khuwarzmi. See Figure 5 [15].

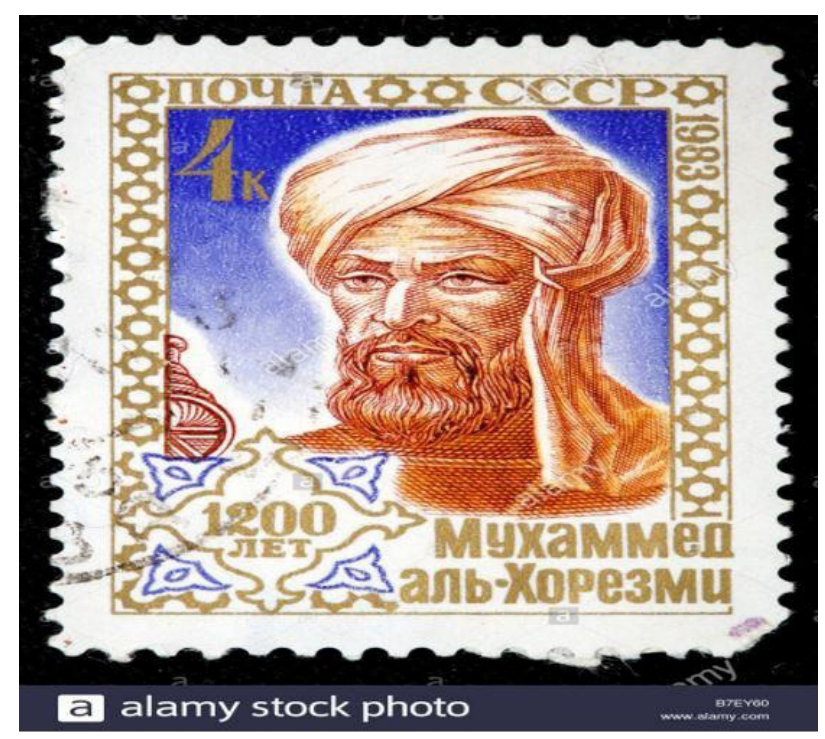

FIGURE 5. Postage stamp issued by the Russian government in 1983 in the recognition of services rendered by al-Khuwarzmi. Source: https://www.alamy.com.

5- Jabir ibn Hayyan also known as Geber (721-815 A.D): The father of Chemistry and founder of principles of scientific experiments and studies. See Figure 6.

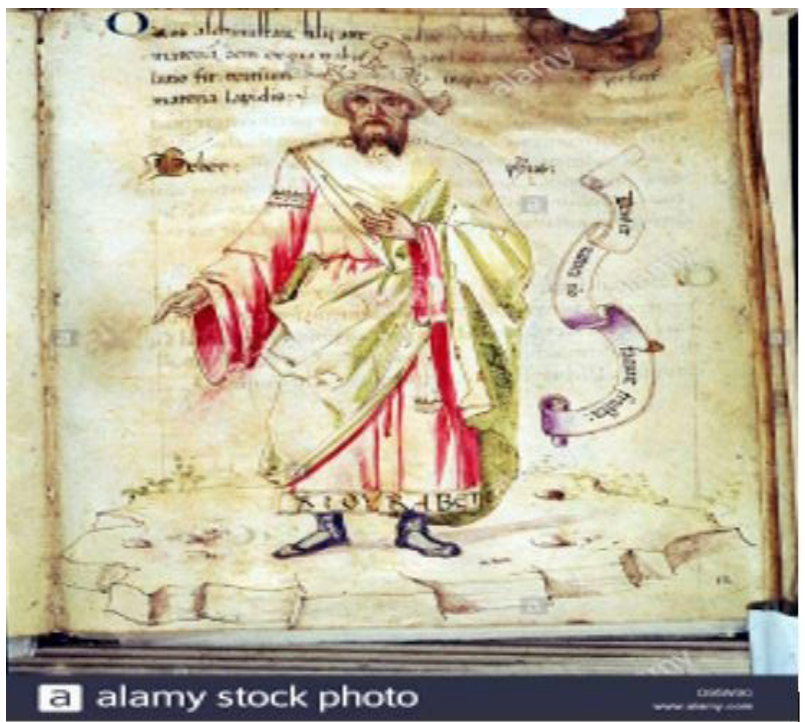

FIGURE 6. Jabir b. al-Hayyan. Source: https://www.alamy.com/stock-photo-jabir-ibnhayyan-abu-musa-. 
6- Ibn al-Haytham (960-1038 A.D): He was an Arab Mathematician, Astronomer, and Physicist of the Islamic Golden Age. Sometimes called "the father of modern optics", he made significant contributions to the principles of optics and visual perception. See Figure 7.

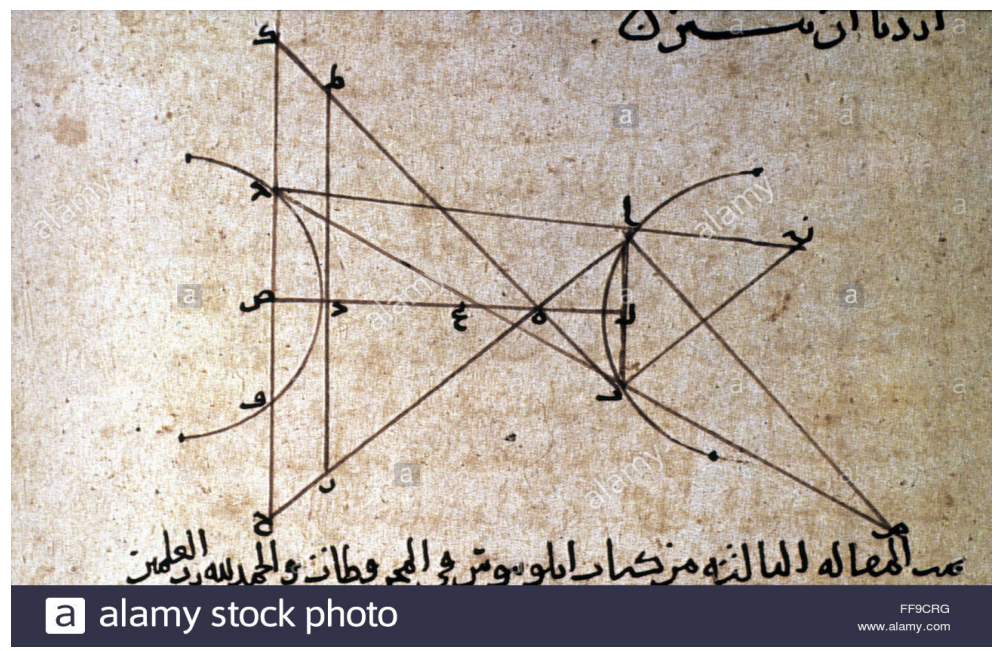

FIGURE 7. Diagram from manuscript on optics by lbn al-Haytham, using mathematical methods, 965-1039 A.D. Source: https://www.alamy.com/stock-photo-arabic-manuscriptoptics-ndiagram-from-manuscript-on-optics-by-ibn.

7- Abul Qasim al-Zahrawi (936-1013 A.D): Renowned physician and founder modern day Surgery. Author of the book "kitab al-Ta'rif" in which he discussed in detail the process of surgery. Book was part of syllabus in many universities of Europe for centuries. See Figure 8 [16-17].

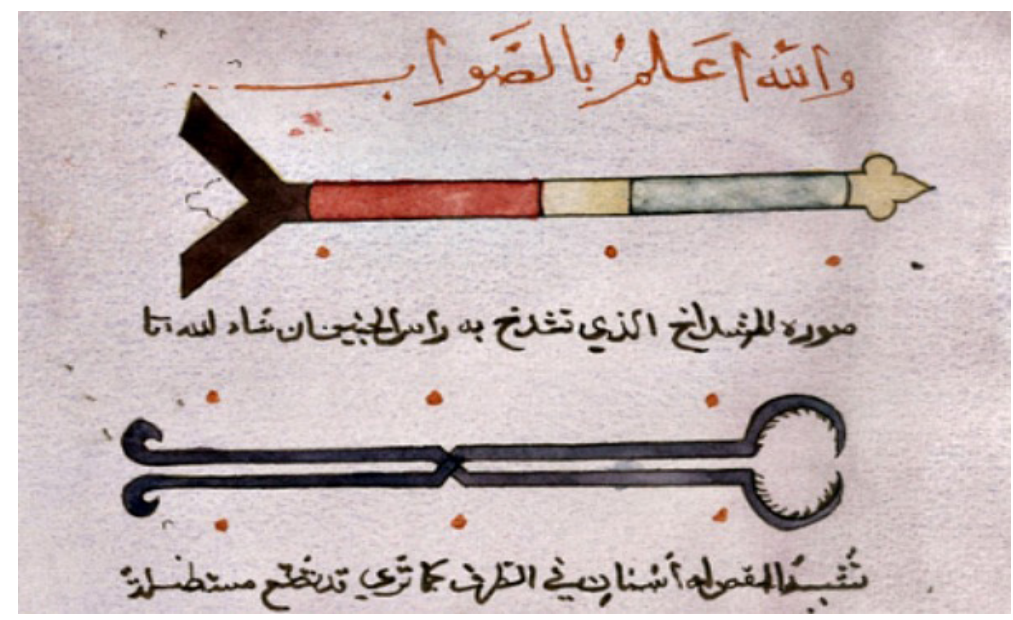

FIGURE 8. Al-Zahrawi's surgical instruments. Source: https://www.europeandefenceleague.com/wp-content/uploads/2017/07/Al-Zahrawi-surgical-instruments.jpg. 
The list is very long, but we have cut it short because we think mentioning some of early Muslim scientists serve the purpose. The works of the above scholars were so qualitative, research-based and authentic that they were included in the syllabus of many European universities and were taught for centuries [18].

\subsection{Contribution of Recent/Contemporary Muslim Scholars}

Though, the position of Muslims of Present time is vastly different from the position of their ancestors and they are no longer in a position to dictate the direction of Science \& Technology as a societal and a national pursuit, living mainly as consumers and borrowers even at the level of ideas and thoughts [19], but still there are many contemporaneous Muslim scientists who by following the footsteps of their ancestors, continued the process of contribution towards scientific development and improvement of human life at individual level. The irony is that the majority of Muslims are unaware of the contribution of current Muslim scientists and think that Muslim Ummah is in deep sleep and have abandoned the creative thinking and scientific approach at large. In the following pages, we will mention such Muslim contributors of modern times whose contributions are not lesser than any Western scientists.

1- Dr. Ali Moustafa Mosharafa (Egyptian Arabic: (تفرشمىفطصمى (11 July 1898-16 January 1950) was an Egyptian theoretical physicist. He was professor of applied mathematics in the Faculty of Science at Cairo University. He contributed to the development of the quantum theory as well as the theory of relativity. In 1924, Mosharafa was awarded the degree of Doctor of Science by King's College London, the first Egyptian and 11 th scientist in the entire world to obtain such a degree. He was contemporaneous to Albert Einstein and had correspondence with him [20].

2- Sameera Moussa (Egyptian Arabic: (1) (March 3, 1917-August 5, 1952) was an Egyptian nuclear physicist who held a doctorate in atomic radiation and worked to make the medical use of nuclear technology affordable to all. She was given the title of Mother of Atomic Energy [21].

3- Rammal Hassan Rammal (Arabic: لصامرنس حلامر) (September 30, 1951-May 31, 1991) was a Lebanese condensed matter physicist. Dr. Rammal research has contributed to build the basics and origins of modern physics and development. The Rammal Award for scientists from Mediterranean countries was created in his honor by the Euro Science organization and has been awarded annually since 1993 [22].

4- Hassan Al Sabbah: Born in Nabatieh, Lebanon, in 1894, Hassan Al Sabbah was an electrical and electronic engineer. His inventions were vastly known and praised, including a pressure monitor that allows one to check the amount of electricity needed for a device to work, and a battery that works on solar energy.

5- Jawed Karim (1979): A Bangladeshi young entrepreneur and co-founder of You Tube [23].

6- Aziz Sancar, (born 8 September 1946): Turkish biochemist, the first Muslim biologist awarded the Nobel Prize. In 2015, he was awarded the Nobel Prize in Chemistry along 
with Tomas Lindahl and Paul L. Modrich for their mechanistic studies of DNA repair [24].

7- Kerim Kerimov, founder of Soviet space program, a lead architect behind first human spaceflight (Vostok 1), and the lead architect of the first space stations (Salyut and Mir) [25].

8- This may seem strange, but it is true that the founder of Apple Steve jobs had genes of a Muslim father as he was the son of Abdul Fattah (al-) Jandali (Arabic: (يلدنجلاحاتفلادبع (b. 1931), grew up in Homs, Syria, and was born into an Arab Muslim household. The biological parents of Steve Jobs put him up for adoption and he was adopted by Paul and Clara Jobs.

These are not fairytales, but the established fact and many non-Muslim intellectuals have admitted the rich contribution of Muslims and their influence on western nations. For example, Gustave Le Bon writes in his book La Civilisation des Arabes that in Europe Some inclination to science did not occur until the eleventh and twelfth century when some people realized that they should lift their heavy paws of ignorance, so they got attention of Arabs who were leader's alone [26]. He quotes Monsieur Leprey as “if the Arabs did not appear on stage of History; Europe's renaissance in literature would have been delayed for several centuries". No doubt that there has been an ambivalence or resistance to technology in the view of some Islamic figures. But that ambivalence can be attributed to factors above or beyond technology. An objection to technology for some religious figures, for example, has been objection to an entity called "the West." Another factor could be the arrival of science in the form of secular education and curriculum. However, the figures approving and accepting scientific and technological advancement have been in the majority [9]. Muslims already have a rich tradition of their involvement in and contribution to science and technology throughout the history, only thing they require now to regain their lost place is the process of social and economic liberalization that can provide a natural driver for innovation and competition [27].

\section{Conclusion}

The above discussion suggests that Islam has never ever been against the advancement of science and technology rather it encourages its followers to actively participate in the scientific activities and ultimately play a role in the social and spiritual development and wellbeing of humans. The earlier and contemporary followers of Islamic doctrine have proven it to be true by contributing in the multidimensional fields of science and technology. The role of Muslims in the fields of science and technology cannot be ignored and overlooked as the history is witness of it. The youth of today should come forward as the heirs of golden history of Muslims in science and technology and make the world feel their presence through their contribution in various fields of science and technology. That is the only way by which Muslims can regain their lost dignity and prestige among the nations of the world. 


\section{References}

1. Embong AH, Wan nor Anas WNI, Mohd H. The application of technology in the dissemination of Fatwas: a study on religious institutions in Malaysia. International Journal of Civil Engineering and Technology. 2018, 9(7), 1590-1596. http://www.iaeme.com/ijciet/IJCIET_Paper.asp?sno= 12406

2. al-Hilali MT-D, Muhsin Khan M. The noble Quran. Dar-us-Salam: Riyadh. https://archive.org/ details/AlMujamAlMufahrasLiAlfazhAlQuran/page/n3. Date accessed: 03/05/2011.

3. Abdul Baqi MF. al-Mu’jamul Mufahris li al-faazilquran al-karim. Maktaba al-Ghazali: Damascus. Nd. https://archive.org/details/mujammufahras/page/n3. Date accessed: 09/02/2016.

4. Daar al-Nawadir. Lahore. https://islamhouse.com/en/source/195947/books/showall/1/. Date accessed: 17/03/2009.

5. Al-Tirmidhi. https://en.wikipedia.org/wiki/Al-Tirmidhi. Date accessed: 19/12/2019.

6. Sunan Ibn Majah. https://en.wikipedia.org/wiki/Sunan_ibn_Majah. Date accessed: 06/12/2019.

7. Sahih Muslim. https://en.wikipedia.org/wiki/Sahih_Muslim. Date accessed: 18/12/2019.

8. Translation of Quran. https://en.wikipedia.org/wiki/Quran_translations. Date accessed: $13 / 01 / 2020$.

9. Semati M, Faraji M, Hamidi YN. Elite discourse on technology in Iran negotiating technology, modernity and Islam. Sociology of Islam. 2016, 4(4), 323-344. https://doi.org/10.1163/ 22131418-00404002

10. Khutabat-e-Bahawalpur. https://www.scribd.com/doc/74280165/khutbat-e-bahawalpur-3. Date accessed: 30/11/2011.

11. Hassan MK. The necessity of studying the natural sciences from the Quranic worldview. In: Islamic perspectives on science and technology. M.H. Kamali, O. Bakar, D.A.F. Batchelor, R. Hashim. D.A.-F. Batchelor, R. Hashim (eds.), Springer: Singapore. 2016; 35-58. https://doi. org/10.1007/978-981-287-778-9

12. Kamali MH, Preface. In: Islamic perspectives on science and technology. M.H. Kamali, O. Bakar, D.A.F. Batchelor, R. Hashim D.A.-F. Batchelor, R. Hashim (eds.), Springer: Singapore. 2016. https://doi.org/10.1007/978-981-287-778-9

13. Kennedy E. Mathematical geography. In: Encyclopedia of the history of Arabic science. Roshdi Rashid (ed), Routledge: New York. 2005; 185-202. https://archive.org/details/RoshdiRasheded. EncyclopediaOfTheHistoryOfArabicScienceVol.3Routledge1996

14. Muslim scientist stock photos \& Muslim scientist stock images - Alamy. https://www.alamy. $\mathrm{com} / \mathrm{search} \cdot \mathrm{html}$ ? CreativeOn $=1 \& \mathrm{adv}=1 \& \mathrm{ag}=0 \&$ all $=1 \&$ creative $=\& \mathrm{et}=0 \mathrm{x} 000000000000000$ $00000 \& v p=0 \& l o c=0 \& q \mathrm{t}=$ muslim $\% 20$ scientist $\& \mathrm{qn}=\& \mathrm{lic}=6 \&$ lic $=1$ \&imgt $=0$ \&archive $=1 \& \mathrm{dtfr}$ $=\& \mathrm{dtto}=\& \mathrm{hc}=\&$ selectdate $=\& \operatorname{size}=0 \mathrm{xFF} \& \mathrm{aq} \mathrm{t}=\&$ epq $\mathrm{t}=\& \mathrm{oq} \mathrm{t}=\& \mathrm{nq} \mathrm{t}=\&$ gtype $=0$. Date accessed: $16 / 12 / 2019$.

15. Al-Khwarizmi: the father of algebra. https:/www.aljazeera.com/programmes/science-in-agolden-age/2015/10/al-khwarizmi-father-algebra-151019144853758.html. Date accessed: $16 / 12 / 2019$.

16. Vernet J, Samsó J. The development of Arabic science in Andalusia. In: Encyclopedia of the history of Arabic science. Roshdi Rashid (ed.), Routledge: New York. 2005; 246-277. https:// archive.org/details/RoshdiRasheded.EncyclopediaOfTheHistoryOfArabicScienceVol.3Routle dge1996

17. Debunking the golden age of Islam \#4: can Al Zahrawi be considered the father of surgery? https://www.europeandefenceleague.com/2017/07/29/debunking-the-golden-age-of-islam-4can-al-zahrawi-be-considered-the-father-of-surgery/. Date accessed: 12/12/2019. 
18. al-Qarzavi Y. Shari'atul Islam. 2nd edn. Daar al-Sahwat li-al-Nashr: Cairo. 1993.

19. Bakar O. Science and technology for mankind's benefit: Islamic theories and practices - past, present, and future. In: Islamic Perspectives on science and technology. M.H. Kamali, O. Bakar, D.A.F. Batchelor, R. Hashim, D.A.-F. Batchelor, R. Hashim (eds.), Springe.: Singapore. 2016; 17-33. https://doi.org/10.1007/978-981-287-778-9

20. These Arab scientists died suddenly and mysteriously. https://stepfeed.com/these-arabscientists-died-suddenly-and-mysteriously-2247. Date accessed: 08/12/2019.

21. TMO. 20th century Muslim scientists - Sameera Moussa. http://muslimobserver.com/20thcentury-muslim-scientists-sameera-moussa/. Date accessed: 08/12/2019.

22. Rammal award attribution by the Euroscience Foundation. https://web.archive.org/ web/20090105212227/http://www.euroscience.org/RAMMAL/rammal.htm. Date accessed: $18 / 12 / 2019$.

23. USATODAY.com - video websites pop up, invite postings. https://usatoday30.usatoday.com/ tech/news/techinnovations/2005-11-21-video-websites_x.htm. Date accessed: 08/12/2019.

24. Nobel prize in chemistry awarded to Tomas Lindahl, Paul Modrich and Aziz Sancar for DNA Studies. https://www.nytimes.com/2015/10/08/science/tomas-lindahl-paul-modrich-azizsancarn-nobel-chemistry.html. Date accessed: 08/12/2019.

25. Behind Soviet Aeronautics from Sputnik to Mir: interview with GeneralKerimKerimov by Betty Blair. http://www.azer.com/aiweb/categories/magazine/33_folder/33_articles/33_sovietaero. html. Date accessed: 18/12/2019.

26. La Civilisation des Arabes. Translated by Adil Za itir. Hindawi Foundation: Cairo. https://www. hindawi.org/books/37926480.pdf. Date accessed: 2012.

27. Maziak W. Science, modernity, and the Muslim world: to improve scientific research in Muslim countries requires profound social and economic liberalization of their societies. EMBO Rep. 2017, 18(2), 194-197. DOI: 10.15252/embr.201643517. 